\title{
SWINE WASTEWATER NITROGEN REMOVAL AT DIFFERENT C/N RATIOS USING THE MODIFIED LUDZACK-ETTINGER PROCESS
}

\author{
Adelcio Giongo ${ }^{1 *}$, Marcelo Bortoli ${ }^{2}$, Marina Celant De Prá ${ }^{3}$, Marcos Veruck $^{4}$, Airton Kunz
}

\author{
${ }^{1 *}$ Corresponding author. State University of Paraná, University Garden - Development Prototypes Building/ Cascavel - PR, Brazil. \\ E-mail: giongoadelcio@gmail.com
}

\section{KEYWORDS}

nitritation/denitritation, nitrification/denitrification, biological nitrogen removal, total organic carbon consumption, animal production wastewater

\begin{abstract}
The swine industry has been presented strong growth and thus is producing large volumes of effluents that must be correctly management. Nitritation/denitritation process can be used to improve system performance, saving the energy cost with aeration and with the external source of carbon due to the lower $\mathrm{C} / \mathrm{N}$ requirement. The aim of this study was to evaluate swine wastewater Nitrification/Denitrification (NDF) and Nitritation/denitritation (NDT) processes at different $\mathrm{C} / \mathrm{N}$ ratios, using the Modified Ludzack-Ettinger (MLE) process, in order to obtain a system with efficient nitrogen removal and low oxygen and carbon consumption. Four phases were conducted during the experiment: Phase I) DO between 2.0-3.0 mg L-1 of $\mathrm{O}_{2}$ and $\mathrm{C} / \mathrm{N}$ 1.5 (NDF); Phase II) DO between 0.6-0.7 $\mathrm{mg} \mathrm{L}^{-1}$ of $\mathrm{O}_{2}$ and $\mathrm{C} / \mathrm{N} 1.5$ (NDT); Phase III) DO between 0.6-0.7 $\mathrm{mg} \mathrm{L}^{-1}$ of $\mathrm{O}_{2}, \mathrm{C} / \mathrm{N}$ ratios of 1.5, 0.9, 0.75 and 0.6 (NDT); Phase IV) DO between 2.0-3.0 mg L $\mathrm{L}^{-1}$ of $\mathrm{O}_{2}, \mathrm{C} / \mathrm{N}$ ratios of 1.5, 0.9, 0.75, and 0.6 (NDF). The best operational condition was found in the $\mathrm{C} / \mathrm{N}$ ratio of 0.9 (Phase III) obtaining an optimum $\mathrm{N}$ removal of $86.3 \%$. In this condition, the system saved around $26.8 \%$ in total organic carbon consumption and operated at conditions of $74 \%$ lower dissolved oxygen when compared to conventional process for N-removal. This strategy can be very useful for nitrogen removal for low carbon swine wastewater as digestate from anaerobic processes.
\end{abstract}

\section{INTRODUCTION}

Worldwide increasing demand for meat has caused the establishment of large concentrated animal feeding operations (CAFOs) for livestock production in order to reduce animal production costs and soil demanded for effluent disposal. Usually intensive breeding farms confine large numbers of animals in an area of land proportionally small, breaking the relationship between crops and animal production. Thus, large amounts of manure are applied to the soil without undergoing any kind of treatment or stabilization, and without considering agronomic and legal criteria (Kunz et al., 2005). According to Williams (2008), much of the environmental impact generated by swine farming is a result of the lack of adequate management of solid and liquid waste. The waste produced in CAFOs often exceeds the amount that can be used as biofertilizer due to land requirement limitations (Kinyua et al., 2014). Nutrient removal, mainly nitrogen and phosphorus from different wastewaters, has become the most important concern for the wastewater treatment plants in the past three decades. Nitrogen can be removed from wastewater by biological and physical chemical processes (Kunz \& Mukhtar, 2016).

The biological Nitrification/Denitrification (NDF) process (Equation 1 and 2) is worldwide used for effluent nitrogen removal when an available carbon source is not a problem. In this process, during the aerobic and autotrophic step (nitrification) $\mathrm{NH}_{4}^{+}$is oxidized to $\mathrm{NO}_{3}{ }^{-}$ followed by the anoxic and heterotrophic step (denitrification) where $\mathrm{NO}_{3}^{-}$is converted to gaseous

${ }^{2}$ Federal University of Technology - Paraná, UTFPR/PPGEA/ Francisco Beltrão - PR, Brazil.

${ }^{3}$ Federal University of Technology - Paraná, UTFPR/ Dois Vizinhos - PR, Brazil.

${ }^{4}$ University of the Contestado/ Concórdia - SC, Brazil.

${ }^{5}$ Embrapa Suínos e Aves/ Concórdia - SC, Brazil.

Received in: 6-20-2018

Accepted in: 9-14-2018 
nitrogen $\left(\mathrm{N}_{2}\right)$ (Lan et al., 2011). Nitrogen removal via nitrite Nitritation/denitritation (NDT) (Eq. 3 and 4) was reported to be technically feasible and economically favorable, especially when treating wastewater with high nitrogen concentrations and low $\mathrm{C} / \mathrm{N}$ ratios (Yang et al., 2007). According to Peng \& Zhu (2006), the methods used to accumulate nitrite are based on the appropriate regulation of temperature, $\mathrm{pH}$, dissolved oxygen, cell retention time and initial nitrogen concentration.

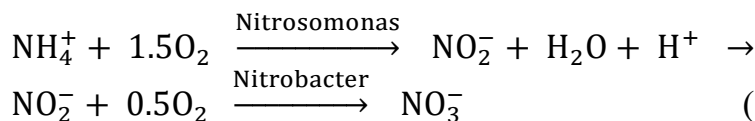

$$
\begin{aligned}
& \mathrm{NO}_{3}^{-} \rightarrow \mathrm{NO}_{2}^{-} \rightarrow \mathrm{NO} \rightarrow \mathrm{N}_{2} \mathrm{O} \rightarrow \mathrm{N}_{2} \\
& \mathrm{NH}_{4}^{+}+1.5 \mathrm{O}_{2} \stackrel{\text { Nitrosomonas }}{\longrightarrow} \mathrm{NO}_{2}^{-}+\mathrm{H}_{2} \mathrm{O}+\mathrm{H}^{+} \\
& \mathrm{NO}_{2}^{-} \rightarrow \mathrm{NO} \rightarrow \mathrm{N}_{2} \mathrm{O} \rightarrow \mathrm{N}_{2}
\end{aligned}
$$

Nitrogen removal via NDT can be achieved by Nitrite Oxidizing Bacteria (NOB) inhibition (e.g.. DO restriction, sludge wash out), due to different physiological characteristics and responses to operating conditions in order to restrict nitrite oxidation to nitrate (Ge et al., 2015). For anoxic phase (denitrification or denitritation) the availability of biodegradable organic carbon becomes critical in wastewater with high ammonia concentration and low $\mathrm{C} / \mathrm{N}$ ratio. An alternative to solve this problem is the use of NDT process saving carbon during denitritation step. For this, a possible alternative is the DO reduction, for NOB activity restriction. This process has attracted attention in recent years, especially for treatment of wastewater with low $\mathrm{C} / \mathrm{N}$ ratio (Gujer, 2010; Ge et al., 2015). In this way, nitritation can be obtained and maintained at low DO concentration.

The present study aims the NDT establishment by DO restriction evaluating the influence of different $\mathrm{C} / \mathrm{N}$ ratios on TOC (Total Organic Carbon) consumption and $\mathrm{N}$ removal efficiency comparing NDF and NDT for swine wastewater nitrogen removal.

\section{MATERIAL AND METHODS}

\section{Wastewater Sampling and Characterization}

The wastewater samples were collected from a swine manure treatment system (SMTS) at Embrapa Swine and Poultry, located in Concordia, Santa Catarina, Brazil. For the experiments, were used the primary settling tank effluent (STE), and the UASB reactor effluent (URE), in order to have samples at different $\mathrm{C} / \mathrm{N}$ ratios (Table1).

\section{Experimental design}

A schematic representation of the experimental MLE (modified Ludzak-Etinger) process configuration, that was under operation at laboratory scale in Embrapa Swine and Poultry, is presented in Figure 1. The aeration was provided using an air pump (Big Air, A420) and controlled by a dissolved oxygen controller (Hach, $\mathrm{SC200})$. The anoxic reactor was continuously fed $\left(\mathrm{Q}_{\text {in }}=\right.$

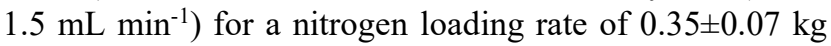
$\mathrm{m}^{-3} \mathrm{~d}^{-1}$ of $\mathrm{N}$ ), the recirculation rate was equivalent to $5.5^{*} \mathrm{Q}_{\text {in }}$ and the sludge recirculation rate was $1 * \mathrm{Q}_{\text {in }}$ using peristaltic pumps (Masterflex, 7518-60). The anoxic and oxic reactors were maintained under continuous stirring (IKA-RW90) at $15 \mathrm{rpm}$ and $200 \mathrm{rpm}$, respectively.

TABLE 1. Characterization of swine wastewater samples collected at a swine manure treatment process used to feed the MLE process configuration.

\begin{tabular}{ccc}
\hline & STE & URE \\
\hline $\mathrm{NH}_{3}-\mathrm{N}\left(\mathrm{mg} \mathrm{L}^{-1}\right)$ & $770 \pm 99.3$ & $767 \pm 47.3$ \\
TOC $\left(\mathrm{mg} \mathrm{L}^{-1}\right)$ & $1200 \pm 380$ & $235 \pm 111$ \\
Alkalinity $\left(\mathrm{mg} \mathrm{L}^{-1}\right)$ & $4000 \pm 536$ & $4000 \pm 541$ \\
C/N Ratio & 1.5 & 0.3 \\
\hline
\end{tabular}

Where: STE: settling tank effluent, URE: UASB reactor effluent and TOC: Total Organic carbon

The study was conducted in four different phases:

Phase I (presence of $A O B$ and $N O B$ at high $D O$ concentration, NDF process), between days 1 - 37, DO concentration in the oxic reactor between $2.0-3.0 \mathrm{mg} \mathrm{L}^{-1}$ of $\mathrm{O}_{2}$. The system influent was composed by the STE presenting a TOC and $\mathrm{NH}_{3}-\mathrm{N}$ concentration of $1,100 \mathrm{mg}$ $\mathrm{L}^{-1}$ of $\mathrm{N}$ and $719 \mathrm{mg} \mathrm{L}^{-1}$ of $\mathrm{N}$ respectively, $\mathrm{C} / \mathrm{N}$ ratio of 1.5 .

Phase II (DO concentration reduction favoring inhibition of $N O B, N D T$ process) was conducted between days 38-101. At the first 20 days (38-53) the DO concentration in oxic tank was kept between 0.5 to $0.6 \mathrm{mg}$ $\mathrm{L}^{-1}$ of $\mathrm{O}_{2}$, from day 54 to 67 , the DO concentrations ranged from 0.4 to $0.5 \mathrm{mg} \mathrm{L}^{-1}$ of $\mathrm{O}_{2}$, and between days $68-101$ with DO concentration between 0.6 to $0.7 \mathrm{mg} \mathrm{L}^{-1}$ of $\mathrm{O}_{2}$. The system influent was fed with SMTS STE with TOC and $\mathrm{NH}_{3}-\mathrm{N}$ concentration of $1,097 \mathrm{mg} \mathrm{L}^{-1}$ and $734 \mathrm{mg} \mathrm{L}^{-1}$ of $\mathrm{N}$ respectively, resulting in a $\mathrm{C} / \mathrm{N}$ ratio of 1.5 .

Phase III (reduction of DO concentration favoring inhibition of NOB, NDT process), days 139 - 170, DO concentration in the nitrifying reactor between $0.6-0.7 \mathrm{mg}$ $\mathrm{L}^{-1}$ of $\mathrm{O}_{2}$. The system influent was fed with the SMTS URE and STE mixture. The mixtures were prepared to provide different $\mathrm{C} / \mathrm{N}$ ratios, 1.5 (101 - 115 days), 0.9 (116 - 135 days), 0.75 (136 - 149 days), and 0.6 (150 - 170 days).

Phase IV (presence of $A O B$ and NOB at high DO concentration, NDF process) was conducted between days 171 - 226 with oxic reactor DO concentration setted between $2.0-3.0 \mathrm{mg} \mathrm{L}^{-1}$ of $\mathrm{O}_{2}$. The oxic reactor was fed with an URE and STE mixture to reach a $\mathrm{C} / \mathrm{N}$ ratios of 1.5 (171 - 180 days), 0.9 (183 - 194 days), 0.75 (197 - 211 days), and 0.6 (212 - 226 days). 


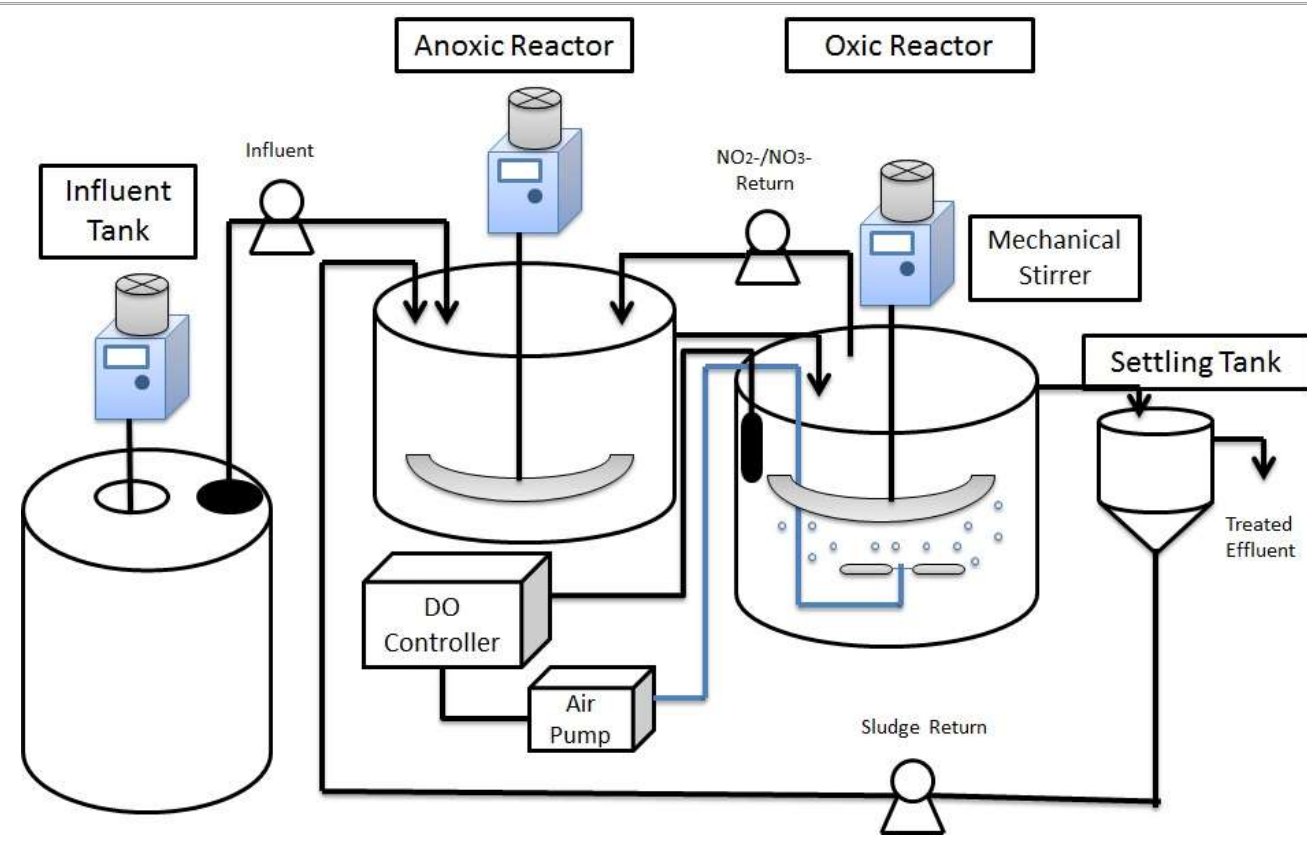

FIGURE 1. Schematic representation of the modified Ludzak-Etinger (MLE) process configuration for swine wastewater treatment. Oxic reactor $=$ Nitritation or Nitrification, anoxic $=$ denitritation or denitrification.

\section{Oxygen Uptake Rates (OUR) on NDF and NDT Activity}

The respirometer, consisted of a $400 \mathrm{~mL}$ glass conical flask with three exits at the top for an oxygen probe insertion (Hanna, HI 98186), a pH probe (Hanna, HI 98183) and the injection of the ammonium solution $\left(\mathrm{NH}_{4} \mathrm{Cl}\right)$ (De Prá et al., 2016). All nitrifying (Phase I: NDF and Phase II: NDT) respirometric tests were carried out at the same biomass concentration $\left(0.47 \mathrm{~g} \mathrm{~L}^{-1}\right.$ of VSS) with the biomass provided from the oxic reactor. A nutrient solution without total ammonia nitrogen (TAN), described by Campos et al. (1999), was prepared to carry out the washing of biomass between tests through suspension, centrifugation and discarding the supernatant. Once the mixed liquor reached DO saturation $\left(9.0 \pm 0.5 \mathrm{mg} \mathrm{L}^{-1}\right.$ of $\mathrm{O}_{2}$ ), ammonia substrate $\left(\mathrm{NH}_{4} \mathrm{Cl}\right)$ was added to the flask at concentrations of 50, 100, 200, 400, 600 and $800 \mathrm{mg} \mathrm{L}^{-1}$ of $\mathrm{NH}_{3}-\mathrm{N}$. DO depletion was monitored until the concentration decreased to $15 \%$ of the DO saturation. The specific oxygen uptake rate (SOUR) was determined by $[$ eq. (5)].

$$
\operatorname{SOUR}\left(\mathrm{mgO}_{2} \cdot \mathrm{gSSV}^{-1} \cdot \mathrm{min}^{-1}=\frac{\mathrm{OUR}\left(\mathrm{mgO}_{2} \cdot \mathrm{min}^{-1}\right)}{\mathrm{X}(\mathrm{gSSV})}-\mathrm{ER}\left(\mathrm{mgO}_{2} \cdot \mathrm{gSSV}^{-1} \cdot \mathrm{min}^{-1}\right)\right.
$$

Where:

SOUR: Specific Oxygen Uptake Rate $\left(\mathrm{mgO}_{2} \cdot \mathrm{gSSV}^{-1} \cdot \mathrm{min}^{-1}\right)$;

OUR: Oxygen Uptake Rate (mg. $\min ^{-1}$ of $\mathrm{O}_{2}$ );

$\mathrm{X}$ : biomass concentration ( $\mathrm{g}$ of SSV),

ER: endogenous respiration $\left(\mathrm{mgO}_{2} \cdot \mathrm{gSSV}^{-1} \cdot \mathrm{min}^{-1}\right)$.

\section{Analytical Methods}

Alkalinity, TOC, $\mathrm{NO}_{2}^{-}-\mathrm{N}, \mathrm{NO}_{3}^{-}-\mathrm{N}$ and $\mathrm{NH}_{3}-\mathrm{N}$ was determined according to APHA, AWWA, WEF (2012). TOC analyzes were performed using a TOC analyzer (Analytik Jena, Multi C/N 2100). While $\mathrm{NO}_{2}^{-}-\mathrm{N}, \mathrm{NO}_{3}{ }^{-}-\mathrm{N}$ and $\mathrm{NH}_{3}-\mathrm{N}$ were determined based on a colorimetric method using a flow injection analysis system (FIAlab 2500). Alkalinity was determined using the titrimetric method (Titronic T-200semiautomatic). DO concentrations in oxic reactor were measured and controlled using a DO controller (Hach, SC200).

\section{RESULTS AND DISCUSSION}

\section{DO restriction effect on NDF process}

At the beginning of phase I the main objective was to keep the conventional NDF process. Throughout this stage, between day 1 - 37, the system presented an $\mathrm{N}$ removal efficiency of $82.3 \%$, with $70 \%$ of TOC consumption (Figure 2). During this phase NDF process has been successfully established and kept during the 37 days. 


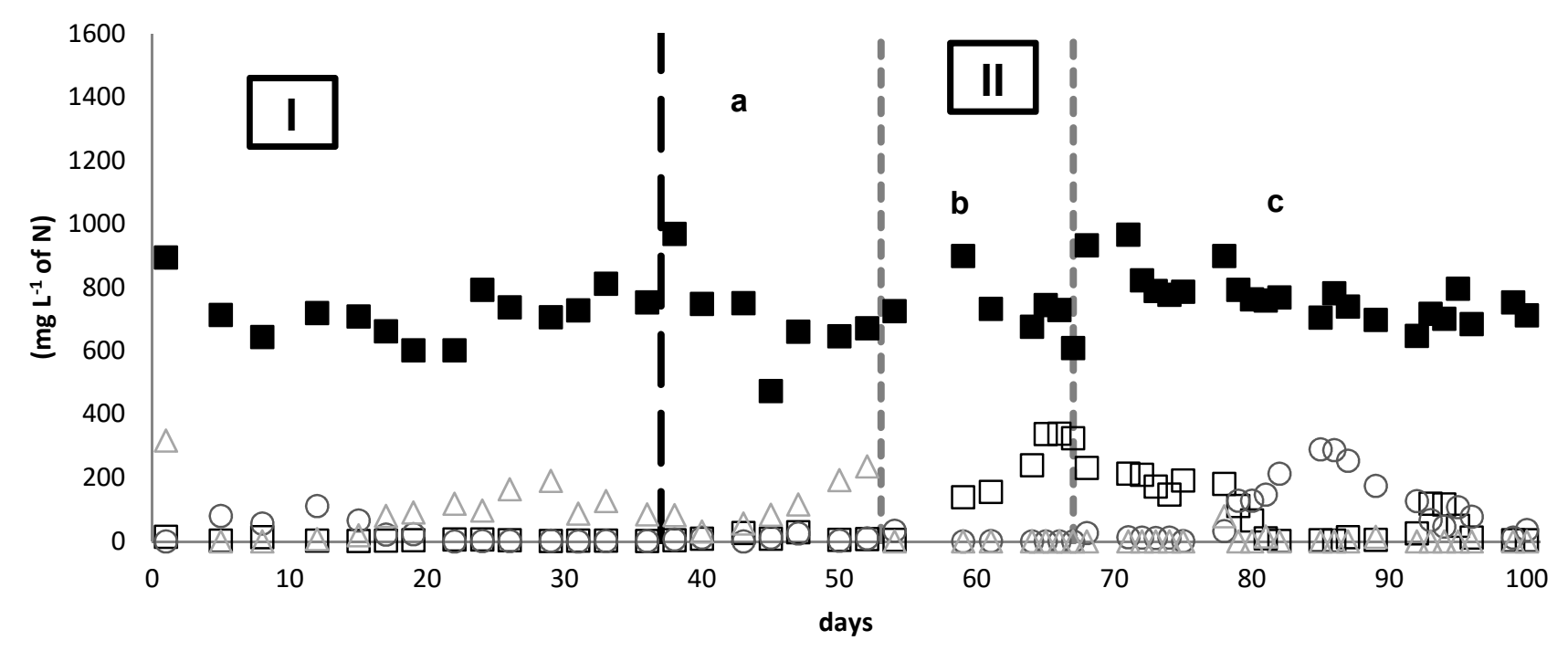

FIGURE 2. Nitrogen species concentrations $\left(\mathrm{NH}_{3}-\mathrm{N}_{\text {in }} \boldsymbol{\square}, \mathrm{NH}_{3}-\mathrm{N}_{\text {out }} \square, \mathrm{NO}_{2}-\mathrm{N}_{\text {out }} \mathrm{O}, \mathrm{NO}_{3}-\mathrm{N}_{\text {out }} \triangle\right.$ ) in the MLE process configuration treating swine wastewater. Phase I: NDF C/N 1.5, DO 2.0 - 3.0 $\mathrm{mg} \mathrm{L}^{-1}$ of $\mathrm{O}_{2}$. Phase II: NDT C/N 1.5, (a) DO 0.5 - $0.6 \mathrm{mg} \mathrm{L}^{-1}$ of $\mathrm{O}_{2}$, (b) DO $0.4-0.5 \mathrm{mg} \mathrm{L}^{-1}$ of $\mathrm{O}_{2}$, (c) DO $0.6-0.7 \mathrm{mg} \mathrm{L}^{-1}$ of $\mathrm{O}_{2}$.

Phase II, between days 38 - 53 (Figures 2 and 3, IIa) DO concentration was restricted from $2.5 \pm 0.5 \mathrm{mg} \mathrm{L}^{-1} \mathrm{of}$ $\mathrm{O}_{2}$ to $0.55 \pm 0.05 \mathrm{mg} \mathrm{L}^{-1}$ of $\mathrm{O}_{2}$, to reduce nitrite oxidation bacteria (NOB) activity (Hanaki \& Wantawin, 1990). However, even after severe reduction of DO concentration, $\mathrm{N}$ removal efficiency via nitrate presented a low decrease when compared to phase I (Table 2). The literature reports that complete nitrification is kept with higher values of DO concentration of $1.5 \mathrm{mg} \mathrm{L}^{-1}$ of $\mathrm{O}_{2}$ (Yang et al., 2012), while at lower DO levels $0.3-0.7 \mathrm{mg} \mathrm{L}^{-1}$ of $\mathrm{O}_{2}$ nitrite is accumulated by the nitritation process prevalence (Ma et al., 2009; Zeng et al., 2013).

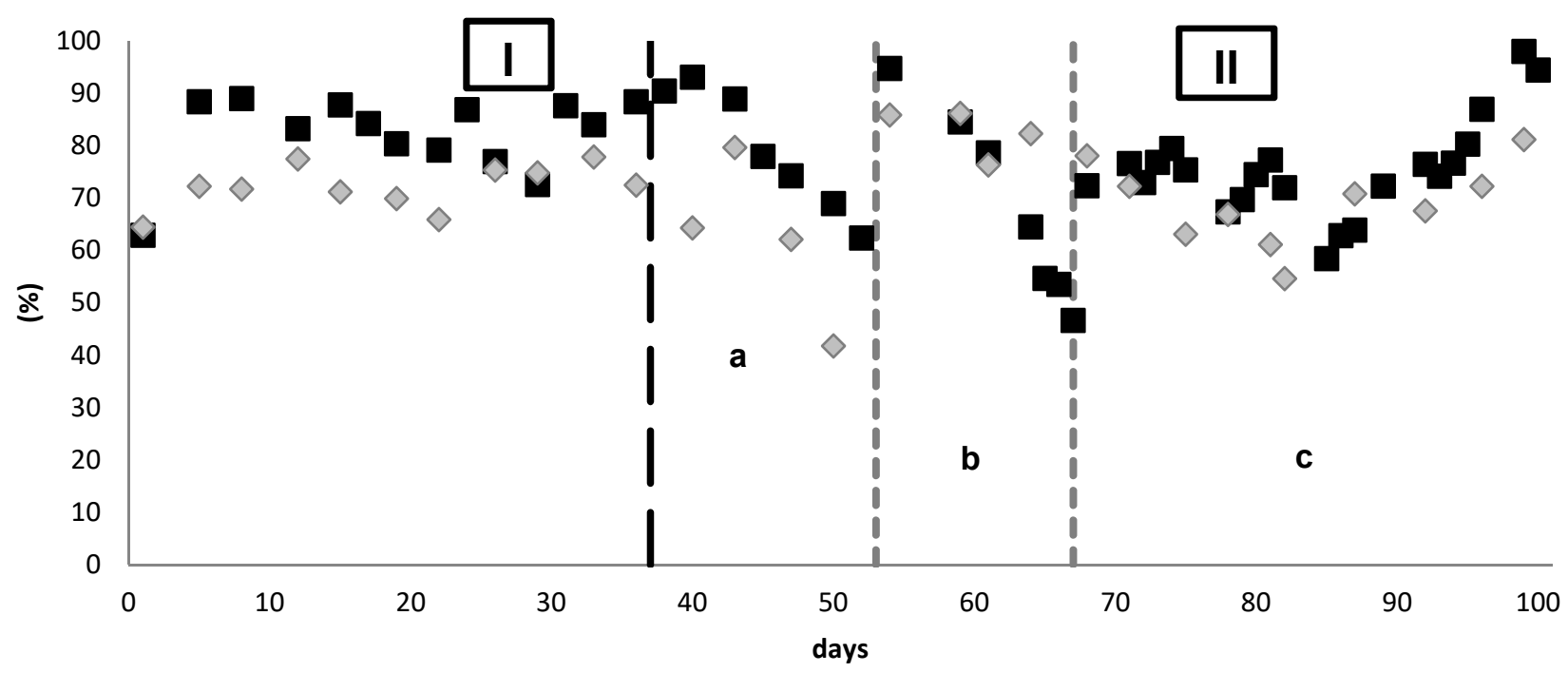

FIGURE 3. N removal $\square$ ) and TOC consumption $\searrow$ ) TOC in MLE process configuration treating swine wastewater. Phase I: $\mathrm{NDF}$ C/N 1.5, DO 2.0-3.0 mg L-1 of O $\mathrm{m}_{2}$ Phase II: NDT C/N 1.5, (a) DO 0.5-0.6 $\mathrm{mg} \mathrm{L}^{-1}$ of O 2 , (b) DO 0.4-0.5 mg L-1 of O DO $0.6-0.7 \mathrm{mg} \mathrm{L}^{-1}$ of $\mathrm{O}_{2}$. 
As nitritation was not stablished in Phase II-a, DO concentration was restricted again in the oxic reactor between days 54-67 (Phase II-b, Figures 2 and 3). The DO concentration was decreased from $0.55 \pm 0.05 \mathrm{mg} \mathrm{L}^{-1}$ of $\mathrm{O}_{2}$ to $0.45 \pm 0.05 \mathrm{mg} \mathrm{L}^{-1}$ of $\mathrm{O}_{2}$. At this condition, it was observed a $\mathrm{NH}_{3}-\mathrm{N}$ accumulation $\left(220.02 \pm 117.4 \mathrm{mg} \mathrm{L}^{-1}\right.$ of $\mathrm{N})$ in oxic reactor, caused by the reduction of $\mathrm{AOB}$ (Ammonia oxidizing bacteria) activity.

On phase II-c, DO concentration was again increased in the oxic reactor from $0.45 \pm 0.05 \mathrm{mg} \mathrm{L}^{-1}$ of $\mathrm{O}_{2}$ to $0.65 \pm 0.05 \mathrm{mg} \mathrm{L}^{-1}$ of $\mathrm{O}_{2}$ (between days 68-101) in order to recover the AOB efficiency to completely remove $\mathrm{NH}_{3}$ $\mathrm{N}$ from the MLE process. During this phase (Figures 2 and 3) $\mathrm{NH}_{3}-\mathrm{N}$ removal was increased about $61 \%$, compared to phase II-b with a slight improvement in $\mathrm{N}$ removal process (Table 2).

\section{Effect of DO concentration and different $\mathrm{C} / \mathrm{N}$ ratios in $\mathrm{N}$ removal process via NDF and NDT}

Initially the system was operated at $\mathrm{C} / \mathrm{N}$ ratio of 1.5 (phase III-a, Figures 4 and 5) and DO $0.65 \pm 0.05 \mathrm{mg} \mathrm{L}^{-1}$ of $\mathrm{O}_{2}$, under the same operating conditions of phase II-c, reaching a similar $\mathrm{N}$ removal efficiency that was also quite similar to phase I when NDF was established (Table 2).
At this phase III-b (between days 116 - 135) $\mathrm{NH}_{3}-\mathrm{N}$ removal was around $90 \%$ (Table 2). However, even with the reduction of $\mathrm{C} / \mathrm{N}$ ratio at this stage to 0.9 , TOC consumption was reduced $23 \%$ when compared to Phase III-a, without significant impact on the $\mathrm{N}$ removal efficiency (Table 2). According to Yang \& Yang (2011), a reduction in the consumption of organic matter switching NDF to NDT can reach in $40 \%$ of carbon economy for heterotrophic process.

Thereafter a new reduction of $\mathrm{C} / \mathrm{N}$ ratio from 0.9 to 0.75 (Phase III-c, Figures 4 and 5) between days 136-149 was performed. This strategy affected the $\mathrm{N}$ removal efficiency in almost $30 \%$ comparing phases III-c with III$\mathrm{b}$ (Table 2). However, with the reduction of $\mathrm{C} / \mathrm{N}$ ratio, there were accumulation of $\mathrm{NO}_{2}^{-}-\mathrm{N}\left(60.11 \pm 21.9 \mathrm{mg} \mathrm{L}^{-1}\right.$ of $\mathrm{N})$ and $\mathrm{NO}_{3}^{-}-\mathrm{N}\left(138.2 \pm 123.5 \mathrm{mg} \mathrm{L}^{-1}\right.$ of $\left.\mathrm{N}\right)$. The accumulation of $\mathrm{NO}_{\mathrm{X}}-\mathrm{N}\left(\mathrm{NO}_{2}^{-}-\mathrm{N}+\mathrm{NO}_{3}^{-}-\mathrm{N}\right)$ occurs when there is absence of TOC in the denitrifying reactor because the TOC is the donor source of electrons, and nitrite and nitrate, are the electrons acceptors. Associated to $\mathrm{NO}_{\mathrm{X}}-\mathrm{N}$ accumulation, and alkalinity consumption, $\mathrm{pH}$ will decrease favoring the generation of Free Nitrous Acid (FNA) that can also cause inhibition on nitrification process (Mohan et al., 2016; Hou et al., 2014).

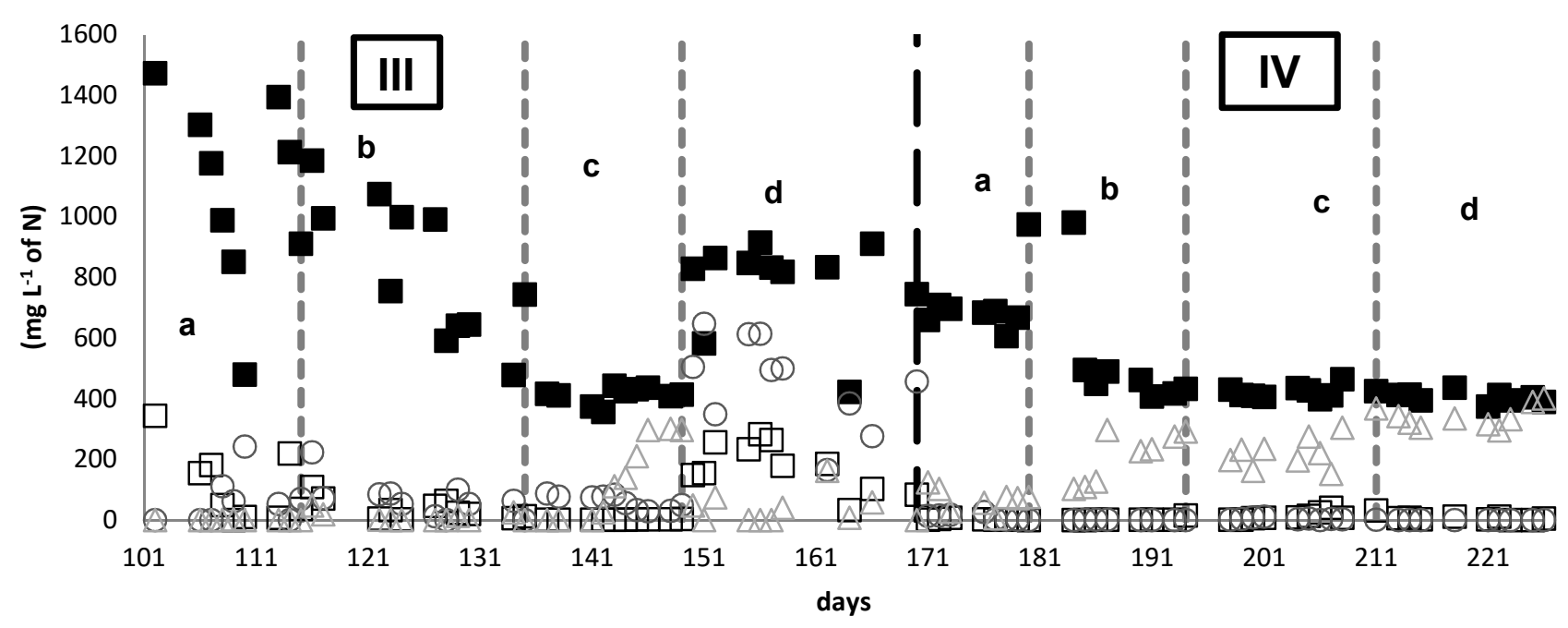

FIGURE 4. Nitrogen species concentrations $\left(\mathrm{NH}_{3}-\mathrm{N}_{\text {in }} \boldsymbol{\square}, \mathrm{NH}_{3}-\mathrm{N}_{\text {out }} \square, \mathrm{NO}_{2}-\mathrm{N}_{\text {out }} \mathrm{O}, \mathrm{NO}_{3}-\mathrm{N}_{\text {out }} \Delta\right.$ ) in MLE configuration process treating swine wastewater. Phase III: DO $0.6-0.7 \mathrm{mg} \mathrm{L}^{-1}$ of $\mathrm{O}_{2}$ and NDF (a) $\mathrm{C} / \mathrm{N} 1.5$; (b) $\mathrm{C} / \mathrm{N} 0.9$; (c) $\mathrm{C} / \mathrm{N} 0.75$; (d) $\mathrm{C} / \mathrm{N} 0.6$. Phase IV: DO 2.0 - $3.0 \mathrm{mg} \mathrm{L}^{-1}$ of $\mathrm{O}_{2}$ and NDT (a) $\mathrm{C} / \mathrm{N} 1.5$; (b) $\mathrm{C} / \mathrm{N} 0.9$; (c) $\mathrm{C} / \mathrm{N} \mathrm{0.75;} \mathrm{(d)} \mathrm{C/N} \mathrm{0.6.}$

In Phase III-d, C/N ratio was decreased to 0.6 (Phase III-d, Figures 4 and 5), between days 150 - 170. During this phase, $\mathrm{N}$ removal efficiency was drastically reduced from $51.93 \%$ (Phase III-c) to $16.10 \%$ (Phase IIId). AOB was probably inhibited by the accumulation of $\mathrm{NO}_{2}{ }^{-}-\mathrm{N}\left(454.8 \pm 143.1 \mathrm{mg} \mathrm{L}{ }^{-1}\right.$ of $\left.\mathrm{N}\right)$ in the system, which occurred by limiting TOC biodegradable. With the absence of TOC heterotrophic bacteria are not capable of converting $\mathrm{NO}_{2}^{-}-\mathrm{N}$. At this high $\mathrm{NO}_{2}-\mathrm{N}$ concentration, for the reactor conditions the FNA concentration was $1.19 \mathrm{mg}$ $\mathrm{L}^{-1}$ of $\mathrm{N}$ that act negatively on the AOB activity (De Prá et al., 2012). 


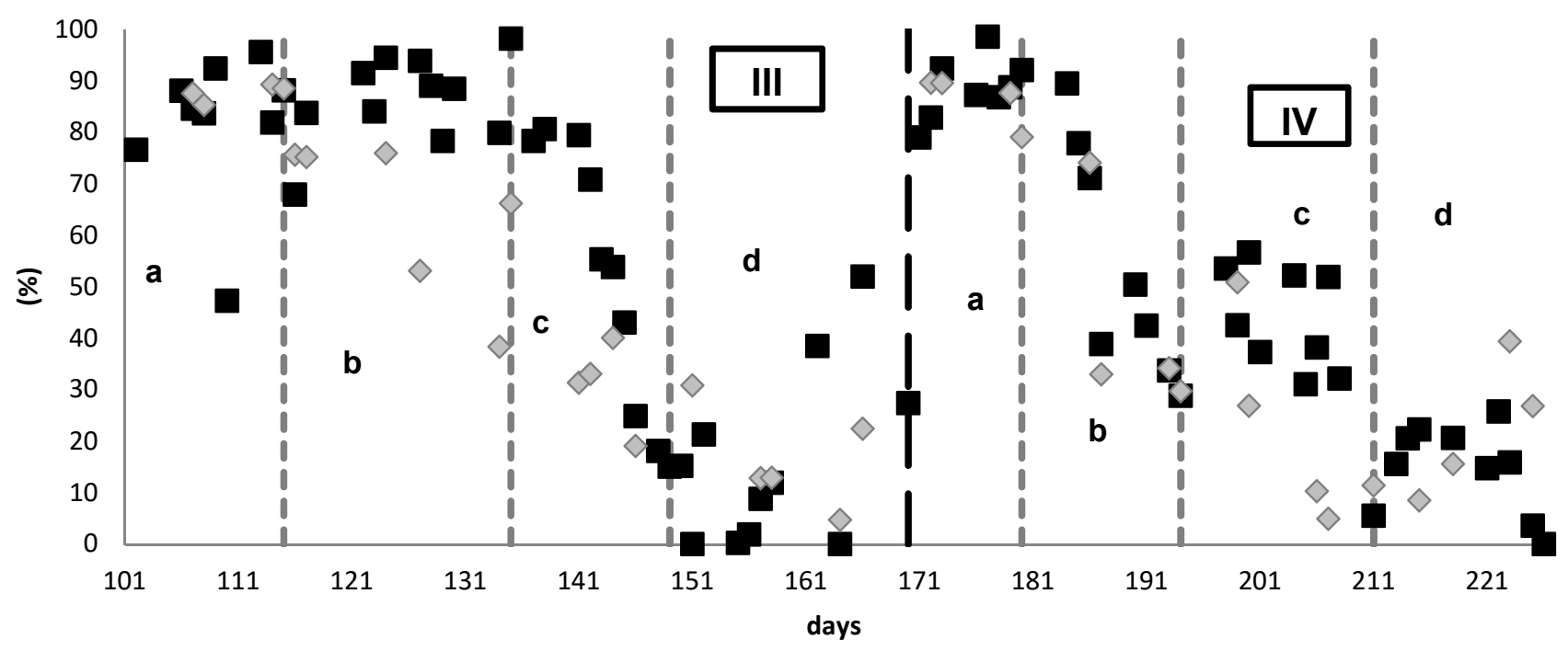

FIGURE 5. N removal ( $(\mathbf{)}$ ) and TOC consumption $(\diamond)$ in MLE configuration process treating swine wastewater. Phase III: DO 0.6 - $0.7 \mathrm{mg} \mathrm{L}^{-1}$ of $\mathrm{O}_{2}$ and $\mathrm{NDF}$ (a) $\mathrm{C} / \mathrm{N} \mathrm{1.5;} \mathrm{(b)} \mathrm{C} / \mathrm{N} \mathrm{0.9;} \mathrm{(c)} \mathrm{C} / \mathrm{N} \mathrm{0.75;} \mathrm{(d)} \mathrm{C} / \mathrm{N}$ 0.6. Phase IV: DO $2.0-3.0 \mathrm{mg} \mathrm{L}^{-1}$ of $\mathrm{O}_{2}$ and NDT (a) $\mathrm{C} / \mathrm{N} 1.5$; (b) $\mathrm{C} / \mathrm{N} 0.9$; (c) $\mathrm{C} / \mathrm{N} 0.75$; (d) $\mathrm{C} / \mathrm{N} 0.6$.

When we compare phase III-d (low C/N ratio), with phase II-b (high $\mathrm{C} / \mathrm{N}$ ratio), it can be seen that in both stages the AOB bacteria were affected, with reduced conversion capacity of $\mathrm{NH}_{3}-\mathrm{N}$ to $\mathrm{NO}_{2}^{-}-\mathrm{N}$. By the $\mathrm{O}_{2}$ restriction (Phase II-b), it was observed an accumulation of $\mathrm{NH}_{3}-\mathrm{N}$, at $\mathrm{pH}$ 8.26. At this condition, the generation of FA (Free ammonia) is favored reaching of $41.53 \mathrm{mg} \mathrm{L}^{-1}$ of $\mathrm{N}$, with sufficient concentration to inhibit the AOB activity (De Prá et al., 2012; Kunz \& Mukhtar, 2016).

The main objective of this phase IV, was to compare the behavior of the NDF (Phase IV) with NDT (Phase III), comparing TOC consumption and $\mathrm{N}$ removing.

Initially at phase IV, DO concentration in the oxic reactor was increased from $0.65 \pm 0.05 \mathrm{mg} \mathrm{L}^{-1}$ of $\mathrm{O}_{2}$ to 2.5 $\pm 0.5 \mathrm{mg} \mathrm{L}^{-1}$ of $\mathrm{O}_{2}$, and $\mathrm{C} / \mathrm{N}$ ratio adjusted to 1.5 . At these conditions the $\mathrm{N}$ and TOC removal reached $88.45 \%$ and $86.45 \%$ respectively. Comparing Phase IV-a with Phase III-a (C/N 1.5 and DO $0.65 \pm 0.05 \mathrm{mg} \mathrm{L}^{-1}$ of $\mathrm{O}_{2}$ ) (Table 2) was observed a similar $\mathrm{N}$ removal and TOC consumption in both phases, around $80 \%$ and $87 \%$ respectively.

In order to prove that oxygen was not the limiting agent in the process, $\mathrm{C} / \mathrm{N}$ ratio was successively reduced as performed in phase III. At phase IV-b, $\mathrm{C} / \mathrm{N}$ ratio was reduced from 1.5 to 0.9 (Figures 4 and 5), between days 183 - 194. At this phase, $\mathrm{N}$ removal of $54.07 \%$ showing an efficiency decreasing of $34.38 \%$ compared to phase IV-a. Comparing with Phase III-b (Table 2), it is observed that besides of $\mathrm{O}_{2}$ economy (about $74 \%$ ). Meng et al. (2015) obtained $\mathrm{N}$ removal of $87 \%$ using nitritation/denitritation in an upflow microaerobic sludge reactor (UMSR), operating with swine influent at $\mathrm{C} / \mathrm{N}$ ratio of 0.84 .

In phase IV-c, $\mathrm{C} / \mathrm{N}$ ratio was reduced from 0.9 to 0.75 (Figures 4 and 5) between days 197-211. Compared to Phase IV-b was observed a decrease in the $\mathrm{N}$ removal reaching $40.11 \%$ (Table 2).

$\mathrm{C} / \mathrm{N}$ ratio was reduced from 0.75 to 0.6 (phase IVd, Figures 4 and 5) between days 212-226. Comparing phase IV-d, (high DO and low C/N) to Phase III- $d$ (low $\mathrm{DO}$ and low $\mathrm{C} / \mathrm{N}$ ) it was observed that both processes showed $\mathrm{N}$ removal efficiency around $15 \%$ associated to low TOC consumption.

At Figure 6 is presented the nitrogen removal rate (NRR) comparing nitritation/denitritation (Phase III) and nitrification/denitrification (Phase IV). For $\mathrm{C} / \mathrm{N}$ ratio of 1.5; the NRR was maintained similar for both processes (about $0.27 \mathrm{~kg} \mathrm{~m}^{-3} \mathrm{~d}^{-1}$ of $\mathrm{N}$ ). However, at the $\mathrm{C} / \mathrm{N}$ ratio of 0.9 was observed an NRR for NDT of about $57 \%$ higher when compared to NDF. However at $\mathrm{C} / \mathrm{N}$ ratios of 0.75 and 0.6 low values of NRR were observed showing the effect of carbon restriction on both processes. 


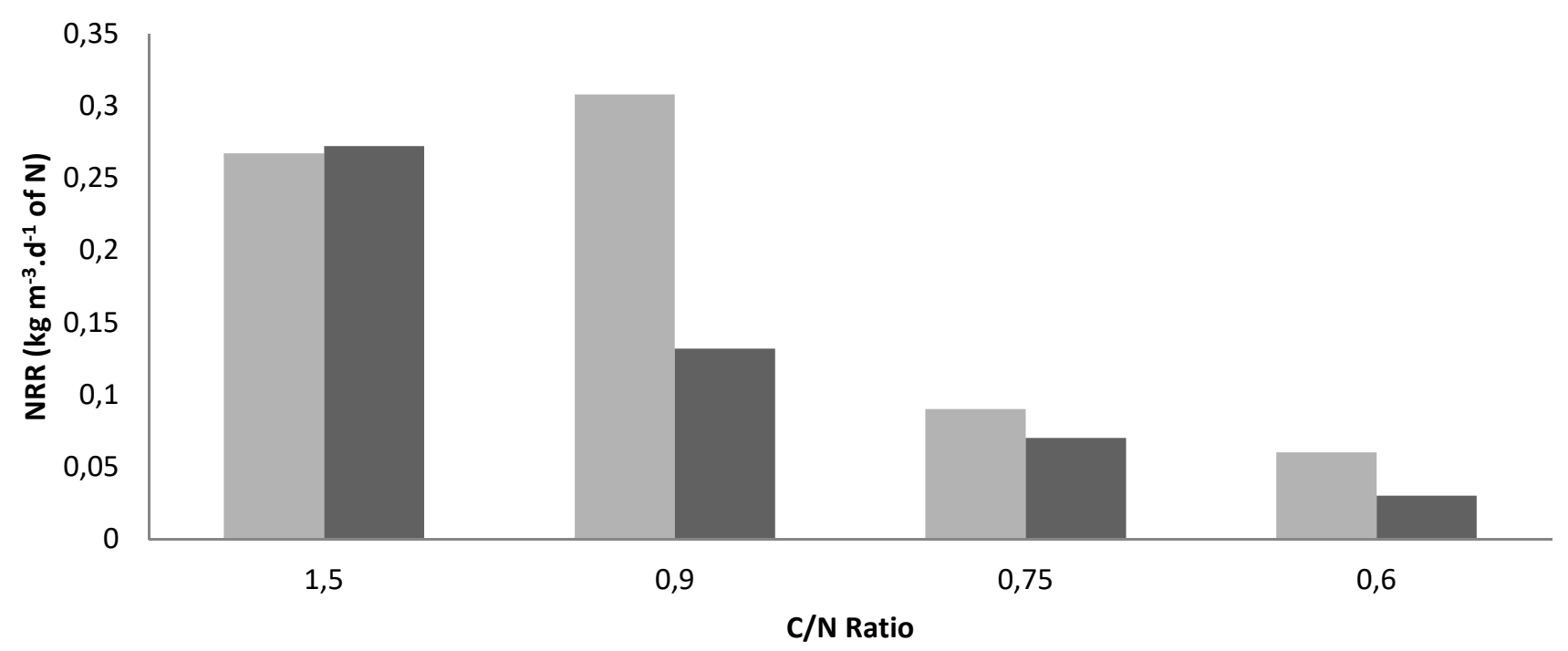

FIGURE 6. Nitrogen Removal Rates (NRR) at Phase III - NDT ( $\square$ ) and Phase IV - NDF ( $\square$ ) C/N ratios in MLE configuration process treating swine wastewater. Phase III (NDT): DO $0.65 \pm 0.05 \mathrm{mg} \mathrm{L}^{-1}$ of $\mathrm{O}_{2}$; Phase IV (NDF): DO $2.5 \pm 0.5$ $\mathrm{mg} \mathrm{L}^{-1}$ of $\mathrm{O}_{2}$

Chen et al. (2015) showed $\mathrm{N}$ removal efficiency higher than $80 \%$ using an anaerobic/anoxic/aerobic $\left(\mathrm{A}^{2}\right.$ /O)-biological aerated filter (BAF) system at $\mathrm{C} / \mathrm{N}$ ratio of 5.5. Hu et al (2014), pointed out that a $\mathrm{C} / \mathrm{N}$ ratio lower than 3.0 makes nitrogen removal from piggery wastewater difficult using NDF process. However, Lackner \& Horn (2013) reached $80-85 \% \mathrm{~N}$ removal with an influent $\mathrm{C} / \mathrm{N}$ ratio of 1 , in a sequencing batch reactor treating industrial wastewater.

\section{Critical Comparison of Specific Oxygen Uptake Rate in NDT e NDF processes}

The concentration of dissolved oxygen during the respirometric tests to determine the endogenous respiration (ER) of NDT and NDF processes showed a linear behavior $\left(\mathrm{R}^{2}=0.951\right.$ and $\mathrm{R}^{2}=0.991$, NDT and NDF respectively), showing a SOUR of $0.043 \mathrm{mgO}_{2} \mathrm{gSSV}^{-1} \mathrm{~min}^{-1}$ and 0.084 $\mathrm{mgO}_{2} \mathrm{gSSV}^{-1} \mathrm{~min}^{-1}$, respectively (Table 3 ). The results of o OUR for each test are presented in Table 3 (Phase I for NDF; Phase II for NDT), and were performed after the process stability to avoid fluctuations in the results. The highest SOURs were observed during the test 3 (Table 3 ) with a $\left(\mathrm{NH}_{4}\right)_{2} \mathrm{SO}_{4}$ concentration nearby $200 \mathrm{mg}$ of $\mathrm{NH}_{3}-\mathrm{N}$, at this condition the oxygen consumption for NDT was around $25 \%$ lower when compared to NDF process.
During the initial tests at $\mathrm{NH}_{3}-\mathrm{N}$ low concentrations (Tests 1 to 3, Table 1), the SOUR $\mathrm{NDF}_{\mathrm{ND}}$ and SOUR $\mathrm{NDT}_{\mathrm{N}}$ had an increasing rates, reaching the highest specific oxygen consumption rate in the test $4\left(\mathrm{SOUR}_{\mathrm{NDF}}=0.323\right.$ $\mathrm{mgO}_{2} \mathrm{gVSS}^{-1} \mathrm{~min}^{-1}$ ) under an initial $\mathrm{NH}_{3}-\mathrm{N}$ concentration of $393.3 \mathrm{mg} \mathrm{L}^{-1}$ and for test $3\left(\mathrm{SOUR}_{\mathrm{NDT}}=0.255 \mathrm{mgO}_{2}\right.$ $\mathrm{gVSS}^{-1} \mathrm{~min}^{-1}$ ) under an initial $\mathrm{NH}_{3}-\mathrm{N}$ concentration of $196.52 \mathrm{mg} \mathrm{L}^{-1}$. After these $\mathrm{S}$ (substrate) concentrations in subsequent tests, the SOURs start to decrease, indicating that this process is more sensitive for concentrations above $200 \mathrm{mg} \mathrm{L}{ }^{-1}$ of $\mathrm{NH}_{3}-\mathrm{N}$. De Prá et al. (2016) observed the beginning of inhibition of nitrifying bacteria after the concentration $200 \mathrm{mg} \mathrm{L}^{-1}$ of $\mathrm{NH}_{3}-\mathrm{N}$, with then downfall in the consumption of oxygen.

Although SOURs were the highest for test 3 (Figure 7 ), the oxygen consumption reduction between NDF and NDT was not the highest found during the respirometric tests. Figure 8 shows the performance between SOURs and $\mathrm{S}\left(\left(\mathrm{NH}_{4}\right)_{2} \mathrm{SO}_{4}\right)$ concentrations for the two studied processes. Whilst for $50 \mathrm{mg} \mathrm{L}^{-1}$ of $\mathrm{NH}_{3}-\mathrm{N} 11.5 \%$ oxygen saving is reached for a $\mathrm{S}$ concentration of $800 \mathrm{mg} \mathrm{L}^{-1}$ of $\mathrm{NH}_{3}-\mathrm{N}$ was achieved around $37 \%$ in oxygen saving (Figure 8), that is higher than that is reported in the literature (Turk \& Mavinic, 1986; Yang \& Yang, 2011; Zhu et al. 2008; Fu \& Zhao, 2015). 


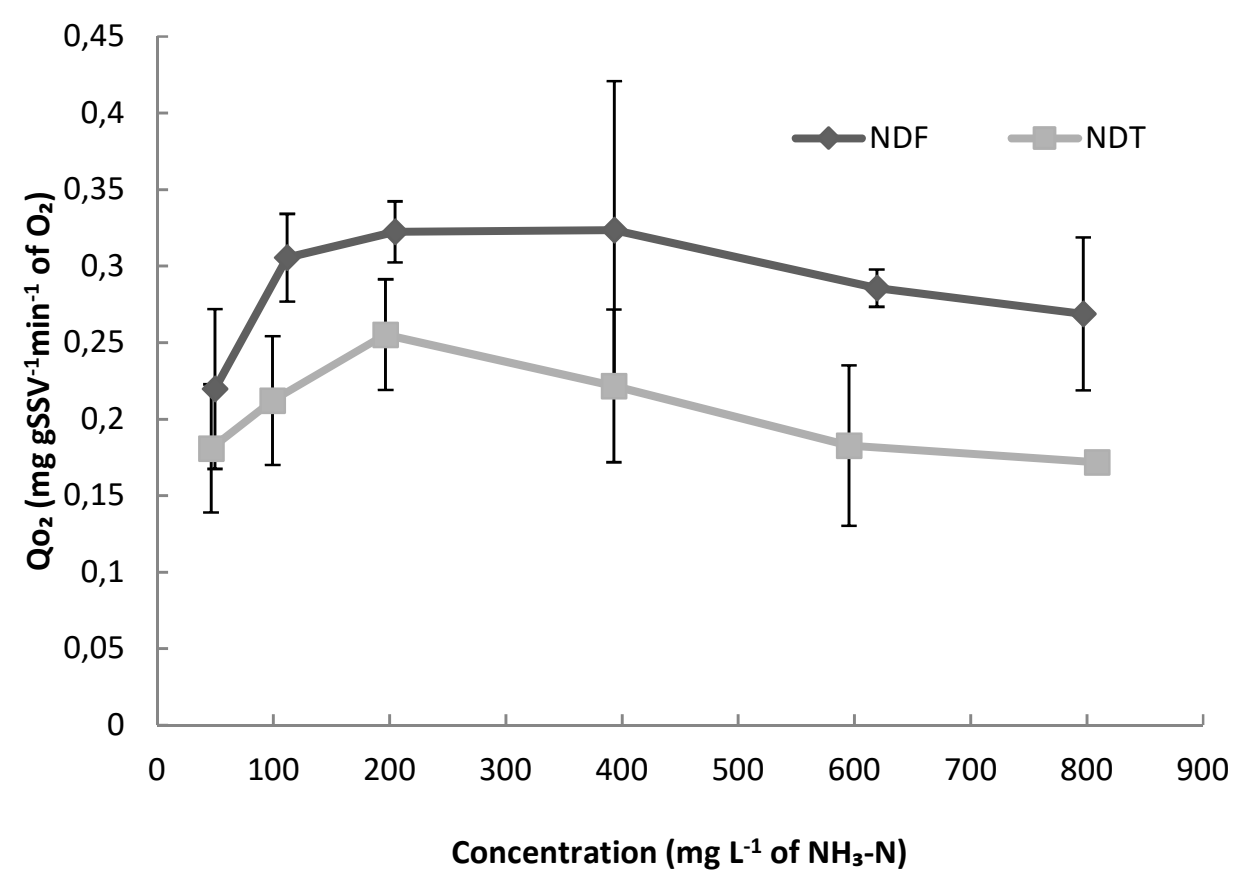

FIGURE 7. Performance of SOUR during the respirometric tests for NDT and NDF processes.

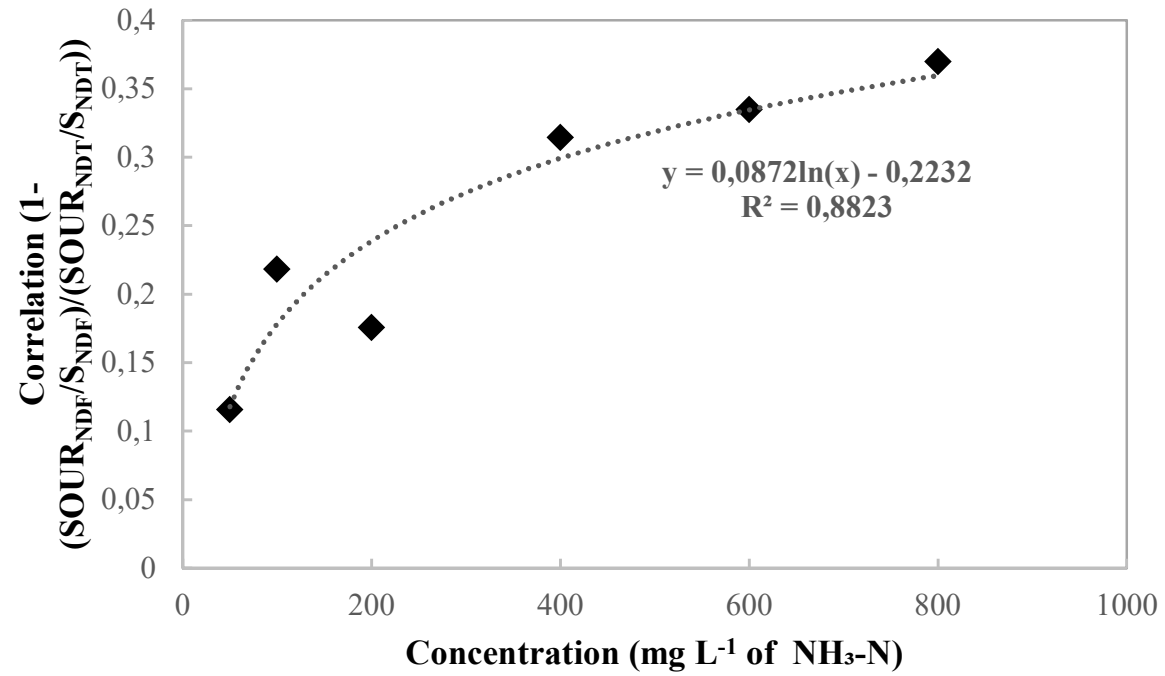

FIGURE 8. Correlation of SOUR and $\mathrm{NH}_{3}-\mathrm{N}$ concentration between NDT and NDF processes.

TABLE 2. $\mathrm{NH}_{3}-\mathrm{N}_{\text {in }}, \mathrm{TOC}_{\mathrm{in}}$ with the respective effluent nitrogen species, TOC and alkalinity consumption and removal efficiencies for swine effluent treatment. Mean values of the parameters in the four phases studied.

\begin{tabular}{|c|c|c|c|c|c|c|c|c|}
\hline Phase & $\begin{array}{l}\mathrm{NH}_{3}-\mathrm{N}_{\text {in }} \\
\left(\mathrm{mg} \mathrm{L}^{-1}\right)\end{array}$ & $\begin{array}{l}\mathrm{NH}_{3}-\mathrm{N}_{\text {out }} \\
\left(\mathrm{mg} \mathrm{L}^{-1}\right)\end{array}$ & $\begin{array}{c}\mathrm{NO}_{2}-\mathrm{N}_{\text {out }} \\
\left(\mathrm{mg} \mathrm{L}^{-1}\right)\end{array}$ & $\begin{array}{c}\mathrm{NO}_{3}-\mathrm{N}_{\text {out }} \\
\left(\mathrm{mg} \mathrm{L}^{-1}\right)\end{array}$ & $\begin{array}{c}\text { Alkalinity } \\
\text { Comsuption } \\
(\%)\end{array}$ & $\begin{array}{c}\mathrm{TOC}_{\text {in }} \\
\left(\mathrm{mg} \mathrm{L}^{-1}\right)\end{array}$ & $\begin{array}{c}\text { TOC } \\
\text { Consumption } \\
(\%)\end{array}$ & $\begin{array}{c}\mathrm{N} \\
\text { Removal } \\
(\%) \\
\end{array}$ \\
\hline $\mathrm{I}^{\mathrm{a}}$ & $719.42 \pm 77.2$ & $4.44 \pm 4.2$ & $26.09 \pm 35.7$ & $98.93 \pm 83.1$ & 84.74 & $1110.2 \pm 41.32$ & 72.18 & 82.28 \\
\hline \multirow{3}{*}{$\mathrm{II}^{\mathrm{b}}$} & $702.4 \pm 138.1$ & $12.41 \pm 9.9$ & $9.62 \pm 7.5$ & $114.2 \pm 68.9$ & 76.07 & $615.2 \pm 219.6$ & 62.01 & 79.45 \\
\hline & $730.7 \pm 81.5$ & $220.0 \pm 117.4$ & $4.83 \pm 11.5$ & 0.00 & 40.38 & $1887.3 \pm 136.0$ & 8.73 & 68.19 \\
\hline & $772.2 \pm 76.9$ & $85.70 \pm 82.6$ & $100.3 \pm 91.8$ & $4.96 \pm 16.8$ & 63.60 & $789.3 \pm 219.7$ & 68.83 & 75.42 \\
\hline \multirow{2}{*}{$\mathrm{III}^{\mathrm{c}}$} & $1087.0 \pm 294.0$ & $111.7 \pm 113.1$ & $60.14 \pm 74.9$ & $0.28 \pm 0.8$ & 52.12 & $1724.9 \pm 27.76$ & 87.64 & 82.02 \\
\hline & $826.2 \pm 219.6$ & $36.00 \pm 32.1$ & $68.38 \pm 59.0$ & $9.97 \pm 15.0$ & 64.23 & $814.2 \pm 61.96$ & 64.06 & 86.3 \\
\hline
\end{tabular}




\begin{tabular}{|c|c|c|c|c|c|c|c|c|c|}
\hline & $\mathrm{c}$ & $411.4 \pm 26.0$ & $2.10 \pm 0.7$ & $60.11 \pm 21.9$ & $138.2 \pm 123.5$ & 92.78 & $269.6 \pm 16.96$ & 30.87 & 51.93 \\
\hline & d & $781.3 \pm 142.7$ & $175.1 \pm 76.5$ & $454.8 \pm 143.1$ & $35.64 \pm 48.1$ & 41.16 & $418.7 \pm 105.13$ & 16.75 & 16.1 \\
\hline \multirow{4}{*}{$\mathrm{IV}^{\mathrm{d}}$} & $\mathrm{a}$ & $710.6 \pm 103.8$ & $2.52 \pm 2.1$ & $9.93 \pm 9.2$ & $67.92 \pm 35.3$ & 64.55 & $1170.5 \pm 88.55$ & 86.45 & 88.45 \\
\hline & $\mathrm{b}$ & $516.5 \pm 177.6$ & $2.77 \pm 5.1$ & $0.56 \pm 0.4$ & $208.0 \pm 77.4$ & 72.66 & $424.1 \pm 72.96$ & 42.75 & 54.07 \\
\hline & $\mathrm{c}$ & $422.0 \pm 17.8$ & $14.52 \pm 12.8$ & $4.29 \pm 3.5$ & $234.4 \pm 62.6$ & 73.09 & $310.8 \pm 43.29$ & 20.87 & 40.11 \\
\hline & d & $403.5 \pm 16.9$ & $5.29 \pm 4.2$ & $0.09 \pm 0.2$ & $337.3 \pm 34.1$ & 79.59 & $254.0 \pm 28.80$ & 22.59 & 15.44 \\
\hline
\end{tabular}

Where:

in = affluent, out $=$ effluent;

aPhase I: C/N ratio 1.5 and DO $2.0-3.0 \mathrm{mg} \mathrm{L}^{-1}$ of $\mathrm{O}_{2}$ (oxic reactor)

${ }^{b}$ Phase II: $\mathrm{C} / \mathrm{N}$ ratio 1.5 and (a) DO $0.5-0.6 \mathrm{mg} \mathrm{L}^{-1}$ of $\mathrm{O}_{2}$; (b) DO $0.4-0.5 \mathrm{mg} \mathrm{L}^{-1}$ of $\mathrm{O}_{2}$; (c) $\mathrm{DO} 0.6-0.7 \mathrm{mg} \mathrm{L}-1$ of $\mathrm{O}_{2}$; (oxic reactor)

'Phase III: DO 0.6 - $0.7 \mathrm{mg} \mathrm{L}^{-1}$ of $\mathrm{O}_{2}$ (oxic reactor) and (a) $\mathrm{C} / \mathrm{N}$ ratio 1.5 ; (b) $\mathrm{C} / \mathrm{N}$ ratio 0.9 ; (c) $\mathrm{C} / \mathrm{N}$ ratio 0.75 ; (d) $\mathrm{C} / \mathrm{N}$ ratio 0.6

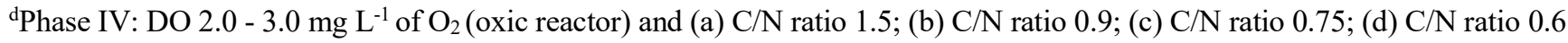

TABLE 3. OUR and SOUR for each substrate $\left(\left(\mathrm{NH}_{4}\right) \mathrm{SO}_{4}\right)$ concentration $(\mathrm{S})$ for NDT and NDF processes.

\begin{tabular}{|c|c|c|c|c|}
\hline Tests & $\begin{array}{c}\mathrm{S}_{\mathrm{NDF}} \\
\left(\mathrm{mg} \mathrm{L}^{-1} \text { of } \mathrm{NH}_{3}-\mathrm{N}\right) \\
\end{array}$ & $\begin{array}{c}\mathrm{S}_{\mathrm{NDT}} \\
\left.\left(\mathrm{mg} \mathrm{L}^{-1} \text { of } \mathrm{NH}_{3}-\mathrm{N}\right)\right)\end{array}$ & $\begin{array}{c}\mathrm{SOUR}_{\mathrm{NDF}} \\
\left(\mathrm{mgO}_{2} \mathrm{gVSS}^{-1} \mathrm{~min}^{-1}\right)\end{array}$ & $\begin{array}{c}\mathrm{SOUR}_{\mathrm{NDT}} \\
\left(\mathrm{mgO}_{2} \mathrm{gVSS}^{-1} \mathrm{~min}^{-1}\right)\end{array}$ \\
\hline ER & - & - & 0.046 & 0.084 \\
\hline 1 & $49.71 \pm 0.05$ & $46.27 \pm 0.04$ & 0.219 & 0.180 \\
\hline 2 & $111.8 \pm 0.03$ & $99.33 \pm 0.04$ & 0.305 & 0.212 \\
\hline 3 & $204.6 \pm 0.02$ & $196.5 \pm 0.04$ & 0.322 & 0.255 \\
\hline 4 & $393.3 \pm 0.09$ & $393.0 \pm 0.05$ & 0.323 & 0.222 \\
\hline 5 & $619.2 \pm 0.01$ & $595.4 \pm 0.05$ & 0.285 & 0.183 \\
\hline 6 & $796.8 \pm 0.05$ & $808.6 \pm 0.01$ & 0.268 & 0.172 \\
\hline
\end{tabular}

$\mathrm{ER}=$ Endogenous respiration.

Figure 8 shows a logarithmic tendency curve indicating a possible stability at substrate concentrations above $800 \mathrm{mg} \mathrm{L}^{-1}$ of $\mathrm{NH}_{3}-\mathrm{N}$. However, a great advantage to operate the NDT process compared to NDF process, maintaining efficiency next to $80 \%$ in $\mathrm{N}$ removal (Table 2 and Figure 5) and parallel consuming less $36.8 \%$ of carbon for denitrification (Figure 6).

\section{CONCLUSIONS}

NDT was successfully stablished for swine wastewater nitrogen removal at DO of $0.6-0.7 \mathrm{mg} \mathrm{L}^{-1}$ of $\mathrm{O}_{2}$, reaching $\mathrm{N}$ removal of $75 \%$. At $\mathrm{C} / \mathrm{N}$ ratio of 0.9 the nitrogen removal rate for NDT reached $0.31 \mathrm{~kg} \mathrm{~m}^{-3} \mathrm{~d}^{-1}$ of $\mathrm{N}$ that is $133 \%$ higher than the obtained for NDF at the same conditions with a reduction of TOC consumption of $27 \%$. The results show that it is possible to obtain efficient nitrogen removal efficiency for MLE configuration process for swine wastewater treatment operating the process at low $\mathrm{DO}$ and $\mathrm{C} / \mathrm{N}$ ratios creating the possibility of application and operating with influent low carbon and high nitrogen, such as digestate from anaerobic processes.

\section{ACKNOWLEDGEMENTS}

Authors thanks financial support from CAPES, CNPq and P-14 Eletrosul.

\section{REFERENCES}

APHA, AWWA, WEF (2012) Standard methods for the examination of water and wastewater. American Public Health Association, 22 ed.

Campos JL, Garrido-Fernández JM, Méndez R, Le-Ma JM (1999) Nitrification at high ammonia loading rates in an acti-vated sludge unit. Bioresourse Technology 68:141145.

Chen Y, Li B, Ye L, Peng Y (2015) The combined effects of $\mathrm{COD} / \mathrm{N}$ ratio and nitrate recycling ratio on nitrogen and phosphorus removal in anaerobic/anoxic/aerobic (A2/O)biological aerated filter (BAF) systems. Biochemical Engineering Journal 93:235-242.

De Prá MC, Kunz A, Bortoli M, Perondi T, Chini A (2012) Simultaneous removal of TOC and TSS in swine wastewater using the partial nitritation process. Journal of Chemical Technology and Biotechnology 87:1641-1647.

De Prá MC, Kunz A, Bortoli M, Scussiato LA, Coldebella A, Vanotti M, Soares HM (2016) Kinetic models for nitrogen inhinition in ANAMMOX and nitrification processo on deammonification system at room temperature. Bioresource Technology 202:33-41.

Fu Z, Zhao J (2015) Impact of quinoline on activity and microbial culture of partial nitrification process. Bioresource Technology 197:113-119. 
Ge S, Wang S, Yang X, Qiu S, Li B, Peng Y (2015)

Detection of nitrifiers and evaluation of partial nitrification for wastewater treatment: A review. Chemosphere 140: 85-98.

Gujer W (2010) Nitrification and me - A subjective review. Water Research 44:11-19.

Hanaki K, Wantawin C (1990) Nitrification at low levels of dissolved oxygen with and without organic loading in a suspended-growth reactor. Water Research 24(3):297-302.

Hou B, Han H, Jia S, Zhuang H, Zhao Q, Xu P (2014) Effect of alkalinity on nitrite accumulation in treatment of coal chemical industry wastewater using moving bed biofilm reactor. Journal of Environmental Sciences (26):1014-1022.

Hu X, Xie L, Shim H, Zhang S, Yang D (2014) Biological nutrient removal in a full scale anoxic/anaerobic/aerobic/pre-anoxic-MBR plant for low $\mathrm{C} / \mathrm{N}$ ratio municipal wastewater treatment. Chinese Journal Chemical Engineers 22(4):447-454.

Kinyua MN, Cunningham J, Ergas SJ (2014) Effect of solids retention time on the bioavailability of organic carbon in anaerobically digested swine waste. Bioresource Technology 162:14-20.

Kunz A, Higarashi MM, Oliveira PA de (2005)

Tecnologias de Manejo e Tratamento de Dejetos de Suínos Estudadas no Brasil Cadernos de Ciência \& Tecnologia 22(3):651-665.

Kunz A, Mukhtar S (2016) Hydrophobic membrane technology for ammonia extraction from wastewaters. Engenharia Agrícola 36(2):377-386.

Lackner S, Horn H (2013) Comparing the performance and operation stability of an SBR and MBBR for singlestage nitritation-anammox treating wastewater with high organic load. Environmental Technology 34(9-12):13191328.

Lan CJ, Kumar M, Wang CC, Lin JG (2011) Development of simultaneous partial nitrification, anammox and denitrification (SNAD) process in a sequential batch reactor. Bioresource Technology 102:5514-5519.

Ma Y, Peng Y, Wang S, Yuan Z, Wang X (2009) Achieving nitrogen removal via nitrite in a pilot-scale continuous pre-denitrification plant. Water Research 43(3):563-572.
Meng J, Li J, Li J, Antwi P, Deng K, Wang C, Buelna G (2015) Nitrogen removal from low COD/TN ratio manurefree piggery wastewater within an upflow microaerobic sludge reactor. Bioresource Technology 198:884-890.

Mohan TVK, Nancharaiah YV, Venugopalan VP, Sai PMS (2016) Effect of $\mathrm{C} / \mathrm{N}$ ratio on denitrification of highstrength nitrate wastewater in anoxic granular sludge sequencing batch reactors. Ecological Engineering 91:441448.

Peng Y, Zhu G (2006) Biological nitrogen removal with nitrification and denitrification via nitrite pathway. Applied microbiology and biotechnology 73(1):15-26.

Turk O, Mavinic DS (1986) Preliminary assessment of a shortcut in nitrogen removal from wastewater. Canadian Journal of Civil Engeenering 13(6):600-605.

Williams CMM (2008) Technologies to mitigate environmental impact of swine production. Revista Brasileira de Zootecnia 37:253-259.

Yang H, Zhang Y, Ye Y (2012) Study on the dissolved oxygen (DO) on the short-cut nitrification in sequencing batch reactor (SBR). Advanced Materials Research 374:1009-1012.

Yang Q, Peng Y, Liu X, Zeng W, Mino T, Satoh H (2007) Nitrogen Removal via Nitrite from Municipal Wastewater at Low Temperatures using Real-Time Control to Optimize Nitrifying Communities Environmental Science \& Technology 41:8159-8164.

Yang S, Yang F (2011) Nitrogen removal via short-cut simultaneous nitrification and denitrification in an intermittently aerated moving bed membrane bioreactor. Journal of Hazardous Materials 195:318-323.

Zeng W, Wang XD, Li BX, Bai XL, Peng YZ (2013) Nitritation and denitrifying phosphorus removal via nitrite pathway from domestic wastewater in a continuous MUCT process. Bioresource Technology 143:187-195.

Zhu G, Peng Y, Li B, Guo J, Yang Q, Wang S (2008) Reviews of environmental contamination and toxicology. New York, Springer. 